\title{
Urbanization, Industrialization, Economic Growth, Energy Consumption and Environmental Damage Nexus: Evidence from Four Highly Populated Asian Countries
}

\author{
SHABANA PARVEEN \\ Assistant Professor, Department of Economics, Hazara University Mansehra. \\ Email: shabana_economist@yahoo.com \\ SOHAIL FAROOQ \\ Assistant Professor, Department of Economics, Hazara University Mansehra. \\ Email: thesohailfarooq@hotmail.com \\ BIBI AISHA SADIQA \\ Assistant Professor, Department of Economics, Hazara University Manshra. \\ Email: agrieco24@yahoo.com

\section{Dr. SHER ALI} \\ Assistant Professor, Department of Economics, Islamia College Peshawar \\ Email: drali@icp.edu.pk
}

\begin{abstract}
Urbanization and industrialization are key factors of economic growth in most of countries which required a lot of energy use, but all the variables are the threat to environmental degradation. The present work is an attempt to test empirically the impact of urbanization, industrialization, growth of economy and energy consumption in four highly populated Asian countries (China, India, Indonesia, Pakistan). The study collected panel data for the span of 1975 to 2018. This study adopted Panel Cointegration and Granger causality technique. The estimates of panel cointegration confirmed long run cointegration between urbanization, industrialization, economic growth, energy consumption and environmental degradation. In addition, the results confirmed positive impact of energy consumtion and economic growth on CO2 emissions which means that both the variables are harmful for environment in the long term. Furthermore, urbanization as well as industrialization is demonstrating negative influence the emissions of CO2 which suggests urbanization and industrialization not have negative effect environment in the selected countries, in the long term. The results of granger causality test confirm three uni-directional causalities as well as three bi-directional causalities among the variables. On the basis of the study results, efficieny in enrgy use is the must for sustainable development and environment in the selected countries.
\end{abstract}

Keywords: Urbanization; Energy Consumption; Industrialization; CO2 Emissions; Panel Cointegration and Most Populous Asian Countries.

\section{Introduction}

Urbanization is a process that transformed a built environment from rural into urban area and also shifts population from rural to urban area. It brings change in occupations, behavior and coulture, life style, demographic as well as social structure of both rural and urban areas (Montgomery et al., 2004). A major impact of urbanization is the increase in land area, number and population of urban areas as compared to rural areas. The buildings and infrastructure shaped both by public and private investment in the process of urbanization. This concentration also increase the share of economic activities, innovation, trade, transfort, 
and information. In urban areas/cities people can enjoy the highest quality of services that are mostly not available in rural areas (WUP, 2018).

The process of urbanization is closely connected with the process of inductrialization. On one hand, urbanization transformed economies from simple agriculture to advanced productive sectors such as industries and services. On the other hand, the world statistics shows that industrial revolution is the motivating factor behind the process of urbanization in the world. Urbanization and industrialization have a direct link (Malik et al., 2017; Raheem and Ogebe, 2017).

Urbanization and industrialization are key factors for a country's economic. During the 19th and 20th centuries, fast urbanization was associated with industrialization and speedy economic growth in Europe and North America (WUP, 2018). The economic history of developed as well as industrialized countries shows that industrialization has a direct link with gross domestic product (GDP) which motivates the process of urbanization in both industrialized and developed countries because of specialization of labor and non- agriculture sectors (Chen et al., 2014). The historical statistics reveals that GDP per capita and urbanization are high in almost all the developed countries. Pugh (1995) and Hope (1998) argued that economic growth motivates industrialization and urbanization so many developing countries have started programs for urbanization and economic growth as they are promoting urbanization as a tool for economic growth.

However, unplanned urbanization is a threat to the natural environment and sustainable development. Empirical studies (Raheem and Ogebe, 2017; Chen et al., 2014; Xuemei et al, 2012) confirmed that urbanization, industrialization have a direct link with economic growth and the desire of most of countries, but all these required a lot of energy; a cause of increase in Carbon Dioxide emissions (CO2 emissions), and a threat to environmental degradation. The environmental degradation has become a hot debatable issue for most of researchers all over the world, due to the ulnerable effects of environmental degradation on climate change, weather conditions smog etc.

York. (2007) found a direct link of urbanization on degradation of environment and argued that due to urbanization, the emissions of $\mathrm{CO}_{2}$ increases that had a negative impact on natural environment. Other studies that support the direct relationship of urbanization with $\mathrm{CO}_{2}$ emissions are Sadorsky (2015), and Zhaohua et al., (2012). Peter et al. (2007) added that urbanization increases consumption of household that contributes to $\mathrm{CO}_{2}$. Likewise, Shahbaz et al. (2014) analyzed impact; urbanization have on degradation of environment for United Arab Emirates (UAE). The data used were for the span of 1975 to 2011. On the basis of Autoregressive distributed lag (ARDL) model, they proved a direct association of urbanization with $\mathrm{CO}_{2}$ emissions. Similarly, Rayhan et al. (2018) for Bangladesh and, Xu and Lin (2015) for China also supported the same positive relationship of urbanization with $\mathrm{CO}_{2}$ emissions. On contrary, Chen et al., (2008) argued that urbanization supports efficient utilization of public infrastructure that reduces energy use and $\mathrm{CO}_{2}$ emissions. Liddle(2004) also have same conclusion in his study. In addition, other empirical studies like, Kasman and Duman (2015) confirmed a unidirectional causality between the two (urbanization and $\mathrm{CO}_{2}$ emissions) for European Union countries whereas, Al-Mulali and Ozturk (2015) showed a causal link between energy consumption and urbanization.

Most of empirical literature about the link between industrialization and emissions of $\mathrm{CO}_{2}$ showed a direct link between the two like, Zou et al. (2014) used ARDL model and found that industrialization as well as energy usage leads to increase environmental degradation as both increases $\mathrm{CO}_{2}$ emissions. Another interesting study of Zhao et al.(2014) showed that urbanization is a motivating factor behind industrialization that both required a lot of energy consumption. They argued that the increased use of capital for industrial purposes and demand of consumption goods increases because of the desire of high living standard that contribute to rise $\mathrm{CO}_{2}$. Shahabaz et al. (2017) and Hosseini and Kaneko (2013) confirmed a direct association of industrialization with $\mathrm{CO}_{2}$ emissions. Some researchers studied the association of industrialization with $\mathrm{CO}_{2}$ emissions on the basis of classification of industries like 
Akbostanci et al. (2009) confirmed a direct association of industrialization with $\mathrm{CO}_{2}$ emissions for manufacturing industry in Turkey. Similarly, Ganzalez and Martimez (2012) analyzed the same for manufacturing industries in Mexico whereas, Moya and Pardo (2013) used data of iron and steel industry in 27 Europeon Union countries and confirmed a strong positive association of industrialization with $\mathrm{CO}_{2}$ emissions. On the contrary, another study of Tian et al. (2014) was conducted in China both at provincial and national level. The study results confirmed that in provincial level due to developed industrial structure and services sectors are not factor behind emissions of $\mathrm{CO}_{2}$ as they are importing more carbon intensive goods and exporting less carbon intensive goods.However, at national level the association of industrialization with $\mathrm{CO}_{2}$ emissions was positive.

Studies like, Wolde (2015), Fodha and Zaghdoud (2010), Dhakal (2009), Song et al (2008), Yang et al (2007) confirmed economic growth has positive effect on environment (reduces environmental degradation). On contrary, Akbostanci et al. (2009) did not confirm this association between income and $\mathrm{CO}_{2}$ emissions for Turkey. Other studies identified mixed results for the impact of energy use on $\mathrm{CO}_{2}$ emissions like, Pata (2017), Jamel and Derbeli (2016), and Hummami and Saidi (2015) found a positive association of energy use with $\mathrm{CO}_{2}$ emissions. On the contrary, Gokmenoglu and Sadeghieh (2019) confirmed negative association of energy usage with emissions of $\mathrm{CO}_{2}$. In addition, Kizilkaya (2017) and, Munir and Khan (2014) confirmed positive association of growth of economy and energy use with $\mathrm{CO}_{2}$. Ali et al. (2016) analysed the data of Nigeria and found the same positive and significant link of these variables with $\mathrm{CO}_{2}$ emissions. However, Thao and Chon (2015) confirmed a negative association of energy usage and growth of economy with $\mathrm{CO}_{2}$ emissions.

Similarly, Kizilkaya (2017), Borhan et al. (2012), Smyth and Lean (2010), supported a direct association of energy use and economic growth with emissions of $\mathrm{CO}_{2}$. Ali et al. (2016) worked on the data of Nigeria, Azam et al. (2016) in China, India, Japan and USA. Poumanyvong and Kaneko (2010) also confirmed a positive significant link between energy use and emissions of $\mathrm{CO}_{2}$ in the countries (China, India, Japan and USA).

Table 1 shows the summary of the literature about the relationship between urbanization, industrialization, economic growth, energy consumption with $\mathrm{CO}_{2}$ emissions.

Table 1. Summary of Earlier Empirical Studies

\begin{tabular}{|c|c|c|c|c|c|}
\hline Auuthors & Sample & Time Span & Variables & Methodology & Results \\
\hline $\begin{array}{l}\text { Sadorsky } \\
\text { (2015) }\end{array}$ & $\begin{array}{l}\text { Emerging } \\
\text { economies }\end{array}$ & $1971-2009$ & $\begin{array}{l}\text { Urbanization, } \\
\text { emissions of } \mathrm{CO}_{2}\end{array}$ & $\begin{array}{l}\text { ARDL, } \\
\text { STIRPAT } \\
\text { model. }\end{array}$ & $\begin{array}{l}\text { An insignificant direct } \\
\text { association of urbanization } \\
\text { with } \mathrm{CO}_{2} \text { emissions. }\end{array}$ \\
\hline $\begin{array}{l}\text { Xu and Lin } \\
\text { (2015) }\end{array}$ & $\begin{array}{l}\text { China's } 30 \\
\text { provinces }\end{array}$ & 1990-2011 & $\begin{array}{l}\text { Urbanization, } \\
\text { Industrialization, } \\
\text { emisions of } \mathrm{CO}_{2}\end{array}$ & $\begin{array}{l}\text { Nonparametric } \\
\text { additive } \\
\text { regression } \\
\text { models }\end{array}$ & $\begin{array}{l}\text { nonlinear } \mathrm{U} \text { shaped association } \\
\text { of Industrialization with } \\
\text { emissions of } \mathrm{CO}_{2} \text { in } 3 \text { regions. } \\
\text { In Eastern Regions, inverted } \mathrm{U} \\
\text { shaped association of } \\
\text { urbanization with emissions of } \\
\mathrm{CO}_{2} \text { while in Central regions, } \\
\text { a U shaped positive } \\
\text { association. }\end{array}$ \\
\hline $\begin{array}{l}\text { Al-Mulali } \\
\text { and Ozturk } \\
(2015)\end{array}$ & $\begin{array}{l}\text { 14 MENA } \\
\text { countries }\end{array}$ & $1962-2012$ & $\begin{array}{l}\text { Urbanization, } \\
\text { industrialization } \\
\text { (industrial } \\
\text { development), } \\
\text { energy } \\
\text { consumption. }\end{array}$ & $\begin{array}{l}\text { fully modified } \\
\text { OLS, Granger } \\
\text { causality test }\end{array}$ & $\begin{array}{l}\text { Causal link exist in all } \\
\text { variables. }\end{array}$ \\
\hline $\begin{array}{l}\text { Azam and } \\
\text { Khan } \\
(2016)\end{array}$ & $\begin{array}{l}\text { Pakistan, } \\
\text { Bangladesh } \\
\text {, Sri Lanka, }\end{array}$ & $1982-2013$ & $\begin{array}{l}\text { Urbanization, } \\
\text { emissions of } \mathrm{CO}_{2}\end{array}$ & $\begin{array}{l}\text { Least square } \\
\text { method }\end{array}$ & $\begin{array}{l}\text { A positive insignificant } \\
\text { association of urbanization } \\
\text { with emissions of } \mathrm{CO}_{2} \text { in }\end{array}$ \\
\hline
\end{tabular}




\begin{tabular}{|c|c|c|c|c|c|}
\hline & India. & & & & $\begin{array}{l}\text { Pakistan, positive significant in } \\
\text { Sri Lanka while in India and } \\
\text { Bangladesh, Negative } \\
\text { assocaitaion of urbanization } \\
\text { with emissions of } \mathrm{CO}_{2} \text {. }\end{array}$ \\
\hline $\begin{array}{l}\text { Siddique et } \\
\text { al (2016) }\end{array}$ & South Asia & $1983-2013$ & $\begin{array}{l}\text { Energy use, } \\
\text { emissions of } \mathrm{CO}_{2} \text {, } \\
\text { economic growth }\end{array}$ & $\begin{array}{l}\text { Panel } \\
\text { cointegration }\end{array}$ & $\begin{array}{l}\text { All the variables have positive } \\
\text { association. }\end{array}$ \\
\hline $\begin{array}{l}\text { Ali et al. } \\
\text { (2016) }\end{array}$ & Nigeria & $1971-2011$ & $\begin{array}{l}\text { Urbanization, } \\
\text { GDP, energy } \\
\text { consumption, } \\
\mathrm{CO}_{2}\end{array}$ & $\begin{array}{l}\text { ARDL Bound } \\
\text { testing } \\
\text { approach }\end{array}$ & $\begin{array}{l}\text { GDP and energy use showed a } \\
\text { significant positive association } \\
\text { with emissions of } \mathrm{CO}_{2} \text {. } \\
\text { Insignificant association of } \\
\text { urbanization with emissions of } \\
\mathrm{CO}_{2} \text {. }\end{array}$ \\
\hline $\begin{array}{l}\text { Sarkodie \& } \\
\text { Owusu } \\
(2017)\end{array}$ & Rwanda & $1965-2011$ & $\begin{array}{l}\text { Population, } \\
\text { Industrialization,e } \\
\text { missions of } \mathrm{CO}_{2} \text {, } \\
\text { per capita GDP. }\end{array}$ & $\begin{array}{l}\text { ARDL, } \\
\text { Granger } \\
\text { causality test }\end{array}$ & $\begin{array}{l}\text { Unidirectional causal } \\
\text { association from } \\
\text { industrialization to per capita } \\
\text { GDP, from population to GDP } \\
\text { per capita, from population to } \\
\text { industrialization, from } \\
\text { population to } \mathrm{CO}_{2} \text {. }\end{array}$ \\
\hline $\begin{array}{l}\text { Raheem } \\
\text { and Ogebe } \\
(2017)\end{array}$ & $\begin{array}{l}20 \text { African } \\
\text { countries }\end{array}$ & $1980-2013$ & $\begin{array}{l}\text { Urbanization, } \\
\text { Industrialization,p } \\
\text { er capita income } \\
\text { and emissions of } \\
\mathrm{CO}_{2}\end{array}$ & $\begin{array}{l}\text { Heterogeneous } \\
\text { panel } \\
\text { estimators }\end{array}$ & $\begin{array}{l}\text { Positive association of } \\
\text { urbanization and } \\
\text { industrialization with } \\
\text { emissions of } \mathrm{CO}_{2} \text {. } \\
\text { Indirect effect (through per } \\
\text { capita income) of urbanization } \\
\text { and industrialization on } \\
\text { emissions of } \mathrm{CO}_{2} \text {. }\end{array}$ \\
\hline $\begin{array}{l}\text { Pata UK } \\
(2017)\end{array}$ & Turkey & $1974-2013$ & $\begin{array}{l}\text { Per capita GDP,. } \\
\text { Per capita energy } \\
\text { consumption, } \\
\text { emssions of } \mathrm{CO}_{2}\end{array}$ & $\begin{array}{l}\text { ARDL bounds } \\
\text { testing } \\
\text { approach }\end{array}$ & $\begin{array}{l}\text { The variables have positive } \\
\text { association with emissions of } \\
\mathrm{CO}_{2} \text {. }\end{array}$ \\
\hline $\begin{array}{l}\text { Hassan } \\
(2018)\end{array}$ & Malaysia & $1976-2013$ & $\begin{array}{l}\text { Emissions of } \\
\mathrm{CO}_{2} \text {, economic } \\
\text { growth, energy } \\
\text { use. }\end{array}$ & $\begin{array}{l}\text { ARDL bound } \\
\text { test, ECM }\end{array}$ & $\begin{array}{l}\text { GDP growth has negative } \\
\text { association with emissions of } \\
\mathrm{CO}_{2} \text {. } \\
\text { Energy use has positive } \\
\text { association with emissions of } \\
\mathrm{CO}_{2} \text {. }\end{array}$ \\
\hline $\begin{array}{l}\text { Liu and } \\
\text { Bae (2018) }\end{array}$ & China & $1970-2015$ & $\begin{array}{l}\text { Urbanization, } \\
\text { industrialization } \\
\text { real GDP, energy } \\
\text { consumption, } \\
\text { emissions of } \mathrm{CO}_{2} \text {. }\end{array}$ & VECM, ARDL & $\begin{array}{l}\text { The variables have positive } \\
\text { association with emissions of } \\
\mathrm{CO}_{2} \text {. } \\
\text { Granger causality is found in } \\
\text { energy consumption, } \\
\text { industrialization, and } \\
\text { emissions of } \mathrm{CO}_{2}\end{array}$ \\
\hline
\end{tabular}

\section{Methodology}

The major objective of the study is test in the highly populated countries of Asia (China, India, Indonesia, Pakistan), the major factors behind degradation of environment. Is it industrialization, urbanization, growth of economy or consumption of energy that is contributing the most in the environmental degradation of the countries. The work is a good contribution in general and for Asia in particulare, for studying the association of industrialization, urbanization, growth of economy and energy use with environmental degradation. 


\section{Data Source and Variables Explanation}

The work is carried out on panel data for four Asian countries namely China, India, Indonesia, Pakistan for the time frame of 1975 to 2018 . These countries are selected because these are the highly populated countries in Asia whose GDP growth is greater than 5\% and energy consumption is higher than other countries in the region. The variables for analysis are urbanization proxied by urban population growth as as percent of total population, industrialization proxied by industry included construction value added annual growth \%, energy use proxied by $\mathrm{kg}$ of oil equalient per capita, growth of economy is proxied by GDP annual growth $\%$ and environmental degradation proxied by $\mathrm{CO}_{2}$ emissions. Data for all these variables are downloaded from World Bank Development Indicators (WDI) which is to the best of our knowledge, the more authentic source for secondary data for these variables.

\section{Model Specifications}

Different methods are used by researchers for analyzind empirically the impact of different macroeconomic factors on environmental degradation $\left(\mathrm{CO}_{2}\right.$ emissions). The study is adopted the analytical techniques of Jamel and Derbali (2016). First for checking the stationarity characteristic of the data different tests that is Levin test, Fisher PP test and Fisher ADF test are applied. For identification of long run association Pesaran et al. (2001) used ARDL test, with mixed integration order. Pesaran and Shin (1999) adopted the same in their work. This research used the same procedure for long term link among the variables.

The present work is following the research technique used by Jamel and Derbali (2016) and Siddique et al. (2016) for analysis for the causal link of urbanization, energy use, industrialization, growth of economy with $\mathrm{CO}_{2}$ emissions.

The proposed model is

$$
\ln C O 2_{\text {it }}=\beta_{0}+\beta_{1} \ln U R_{\text {it }}+\beta_{2} \ln I N D U_{\text {it }}+\beta_{3} \ln E U_{\text {it }}+\beta_{4} \ln G D P G_{\text {it }}+\varepsilon_{\text {it }}
$$

$\mathrm{CO}_{2}$ used for Carbon Dioxide Emissions (Metric tons per capita), UR stands for urbanization ( urban population as \% of total population), INDU stands for industrialization ( industrial including construction value added, annual growth $\%$, EU stands for energy usage ( $\mathrm{kg}$ of oil equalient per capita), GDPG stands for economic growth (GDP annual growth $\%$ ). The parameters are represented by $\beta_{\varepsilon}$ ( $\beta_{1}$ to $\beta_{4}$ ) while $\beta_{0}$ represents intercept of the model. Error term is represented by $\varepsilon_{1 \mathrm{t}}$.

\section{Results and Discussion}

\section{Results of Panel Unit Root Test}

To indentify the stationarity characteristic of all the variables, different unit root tests namely Levin test, Fisher PP test and Fisher ADF test are applied on the data. The all the tests, the null hypothesis is Ho: the series are non stationary / have unit root. P-value is used for the acceptance of rejection of the null hypothesis. According to which if the probability of p-value is below $10 \%$ then the null hypothesis of non stationarity got rejected and vice versa (Jamel and Derbali, 2016).

The reults of all the tests that is Levin test (2002), Fisher PP test and Fisher ADF test are presented in table 2. Names of the variables are presented in first column whereas in first row of the table, the different panel unit root tests are reported. Results of all the tests are presented against each variable where $* *$ indicates 1 percent and * indicates 5 percent significant level respectively. This indicate that two of the varaibles that is GDP and industrialization are stationary at level $\mathrm{I}(0)$ whereas the other three variables that is energy consumption, industrialization and $\mathrm{CO}_{2}$ emissions are stationary at first difference I(1). Pesaran et al.(2001) 
argued that when the order or integration is such that some variables are integrated at level I (0) and other variables are integrated at ist difference I(1), then ARDL is a good method for identifying long run association among variables. This suggests the application of ARDL test to indentify long term association in the variables.

Table-2. Panel Unit Root Test

\begin{tabular}{|lllllll|}
\hline Variables & \multicolumn{2}{l}{ Lin, Levin, and Chu t } & Fisher PP & \multicolumn{3}{l|}{ Fisher ADF } \\
\hline & $\mathbf{I}(\mathbf{0})$ & $\mathbf{I}(\mathbf{1})$ & $\mathbf{I}(\mathbf{0})$ & $\mathbf{I}(\mathbf{1})$ & $\mathbf{I}(\mathbf{0})$ & $\mathbf{I}(\mathbf{1})$ \\
\hline UR & 0.24 & $-1.87^{* *}$ & 3.95 & $41.13^{*}$ & 1.25 & $16.27^{* *}$ \\
INDU & $-2.38^{*}$ & ----- & $-3.03^{*}$ & ------ & $-2.77^{*}$ & ------ \\
EU & -0.09 & $-2.12^{*}$ & 1.23 & $-6.20^{*}$ & 1.98 & $-2.93^{*}$ \\
GDPG & $-6.09^{*}$ & ----- & 2.47 & ---- & $-5.19^{*}$ & ----- \\
CO & 0.47 & $-4.11^{*}$ & 2.47 & $108.7^{*}$ & 2.80 & $-58^{*}$ \\
emissions & & & & & & \\
\hline
\end{tabular}

\section{Results of ARDL Long Run}

ARDL test is used to anayze the long run association among urbanization, industrialization, energy use and economic growth with environmental degradation. The results of ARDL test are given in table 3 which shows that all the studied variables have significant relationship with environmental degradation.

Furthermore, the results shows that the impact of industrialization and urbanization is negative on $\mathrm{CO}_{2}$ emissions in the long run meaning that in the long run, urbanization and industrialization improve environment. Tian et al. (2014) in China supported the same negative influence of industrialization in differet regions. The negative influence of urbanization on $\mathrm{CO}_{2}$ was confirmed by Chen et al. (2008) and Liddle, (2004). Likewise, Azam and Khan (2016) confirmed the same effect in Bangladesh and India, Xu and Lin (2015) for China and Rayhan et al. (2018) for Bangladesh.

The researchers argued that due to urbanization efficient utilization of public infrastruce takes place which reduces energy consumption and $\mathrm{CO}_{2}$ emissions. On contrary, most of researchers confirmed a positive impact of these variables on $\mathrm{CO}_{2}$ namely, Sadorsky (2015), Zhaohua et al., (2012), York. (2007) and Peter et al. (2007). These researchers argued that both urbanization and industrialization leads to increase consumption of house hold as well as capital in organization that positively contribute to energy consumption and $\mathrm{CO}_{2}$ emissions.

Similarly, the result shows that the impact of energy consumption and economic growth on $\mathrm{CO}_{2}$ emissions is positive and significant meaning that both of the variable have negative impact on environment in long time which is supported by, Kizilkaya (2017), Pata (2017), Jamel and Derbeli (2016), Ali et al. (2016), Hummami and Saidi (2015), Borhan et al. (2012) and Smyth and Lean (2010). On contrary, Wolde (2015), Fodha and Zaghdoud (2010), Dhakal (2009), Song et al (2008), Yang et al (2007) confirmed negative impact of growth of economy and use of energy on $\mathrm{CO}_{2}$ emissions (positive impact on environment). These further reveals that $1 \%$ rise in urbanization and industrialization decreases $\mathrm{CO}_{2}$ emissions by $0.013 \%$ and $0.011 \%$. Similarly a $1 \%$ increase in energy consumption and economic growth leads to increase $\mathrm{CO}_{2}$ emissions by $0.003 \%$ and $0.027 \%$.

Table-3: ARDL Long Run

\begin{tabular}{|lllll|}
\hline Variables & Coefficient & Std.Error & t-Statistic & Prob* \\
UR & -0.013360 & 0.003006 & -4.444223 & 0.0000 \\
INDU & -0.011030 & 0.003653 & -3.019699 & 0.0030 \\
EU & 0.003865 & 0.000101 & 38.08187 & 0.0000 \\
GDPG & 0.027474 & 0.004364 & 6.295449 & 0.0000 \\
\hline
\end{tabular}




\section{Results of ECM Model}

ECM is the technique that can be used for identifying short term dynamics along with adjustement speed of dependent variable in the long run if any change occure in independent variables (Saeed, et al., 2018). After confirming long run links in the studied variables, ECM is adopted for identifying short term dynamics of these variables. The estimates of ECM are presented in table 4. It is clear from the results that the speed of adjustement in one year is $0.460 \%$ which means that convergence towards equilibrium will take place at the speed of $0.46 \%$ which is good. The result is also significant as is clear by its t- value and the related P-value.The results further reveals that in the short run urbanization, energy consumption and economic growth reduces $\mathrm{CO}_{2}$ emissions whereas industrialization contributes to increase $\mathrm{CO}_{2}$ in the short period. However, the impact of all the variables in short term is very little.

Table-4: ECM Test Results

\begin{tabular}{|lclll|}
\hline \multicolumn{5}{c|}{ ARDL ECM } \\
\hline Coefficient & Std.Error & t-Statistic & Prob* $^{*}$ \\
\hline D (UR) & -0.163777 & 0.056070 & -2.920937 & 0.0040 \\
D( INDU) & -0.019603 & 0.043749 & -0.448073 & 0.6548 \\
D (EU) & 0.009223 & 0.003497 & 2.637409 & 0.0092 \\
D (GDPG) & -0.000513 & 0.001246 & -0.411842 & 0.6811 \\
COINT(EQ01) & -0.004679 & 0.004688 & -0.998043 & 0.3199 \\
& -0.460718 & 0.069426 & -6.636127 & 0.0000 \\
\hline
\end{tabular}

\section{Results of Granger Causality Test}

Granger causality is a technique that can be used to estimate causal link among variables (Wang, 2013). In the present study, when it got confirmed that long period and short period association exists in the variables, granger causality test is employed to identify the direction of the causal association among the variables under study. Graph 1 represents the results of grander causality test which confirmed three unilateral causalities that is from urbanization to economic growth, from $\mathrm{CO}_{2}$ emissions to energy consumption and from energy consumption to economic growth. These results can be supported (see for example, Sarkodie \& Owusu (2017), Siddique et al. (2016), Mohd et al. (2016).

Furthermore, three bidirectional causalities are also confirmed that is between urbanization and $\mathrm{CO}_{2}$ emissions, urbanization and energy use and between industrialization and economic growth. The results are in line with Liu and Bae (2018) in China, Al-Mulali and Ozturk (2015) in MENA countries,

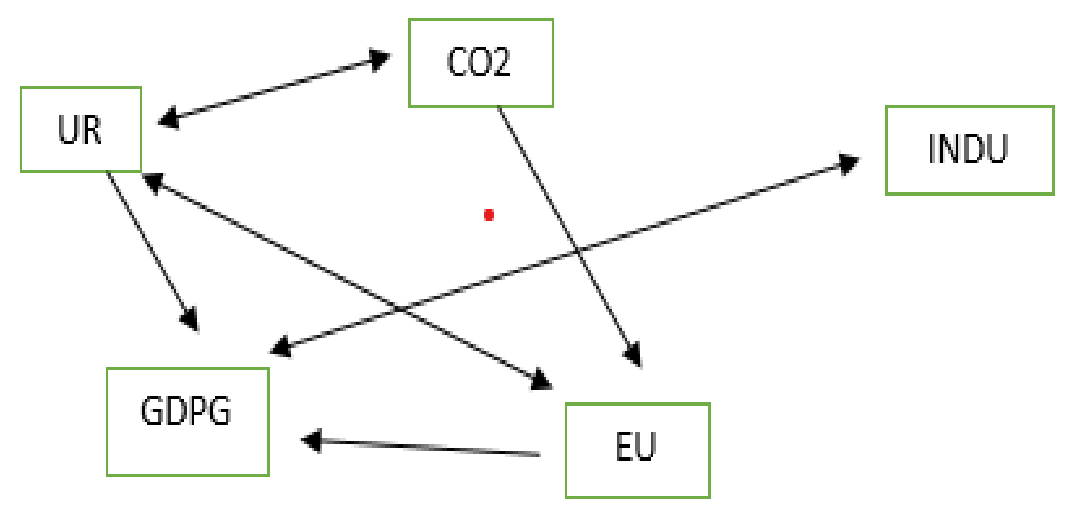

Graph 1. Granger Causality Test 


\section{Conclusion and Policy Implications}

The research study is carried out to analyze the link of industrialization, urbanization, energy use, and growth of economy on environment of 4 highly populated Asian countries (China, India, Indonesia, Pakistan) during the time period of 1975 to 2018. Environmental degradation (proxied by $\mathrm{CO}_{2}$ emissions) is used as endogenous variables whereas urbanization, energy use, economic growth of economy and industrialization are used as exogenous variables. The stationarity characteristic of the variables are check by different tests such as Levin test, Fisher ADF test and Fisher PP test which confirmed that the variables are stationary at mixed order of integration that is at I(0) and I(1). This suggests the use of ARDL approach for testing the long run association in these variables which shows that growth of economy and energy use have positive while urbanization and industrialization have negative influence on degradation of environment in the long run. The results are also statistically significant.

ECM model is adopted for the identification of short term dynamics among the variables. It is clear from the results of ECM that the speed of adjustment during one year is 0.460 percent and it is moving towards convergence. The coefficient of the model identified that urbanization, energy use and economic growth have negative while industrialization has positive impact on $\mathrm{CO}_{2}$ emissions in the short run.

Granger causality approach is used for the causal association which confirmed the presense of three unilateral causalities that is running from urbanization to economic growth, from $\mathrm{CO}_{2}$ emissions to energy use and from energy use to economic growth. Furthermore, three bi-directional causalities are found that is between urbanization and $\mathrm{CO}_{2}$ emissions, $\mathrm{CO}_{2}$ emissions and energy use and between industrialization and economic growth.

The present study recommends the policies regarding efficient use of energy and sustainable development for reducing the emissions of $\mathrm{CO}_{2}$ in the selected countries. In addition, as for urbanization and industrialization is concerned, governments of these countries may work on policies regarding planned urbanization as well as industrialization policies so that to avoid any harmfull effect of these factors on natural environment.

\section{References}

Akbostanci, E., Turut-AsIk, S., \& Ipek, T. G. (2009). The relationship between income and environment in Turkey: is there an environmental Kuznets curve. Energy Policy 37(3): pp. 861-867.

Ali, H. S., Law, H. S., \& Zannah, T. I. (2016). Dynamic impact of urbanization, economic growth, energy consumption, and trade openness on $\mathrm{CO}_{2}$ emissions in Nigeria.Environmental Sciences and Pollution Research, 23(11):

Al-Mulali U., \& Ozturk I. (2015). The effect of energy consumption, urbanization, trade openness, industrial output, and the political stability on the environmental degradation in the MENA (Middle East and North African), Region. Energy, 84: pp. 382- 389.

Azam, M., \& Khan, A. Q. (2016). Urbanization and environmental degradation: Evidence from four SAARC countries-Bangladesh, India, Pakistan, and Sri Lanka. Environmental Progress \& Sustainable Energy, 35(3): pp. 823-832.

Borhan, H., Ahmed, E. M., \& Hitam, M. (2012). The impact of $\mathrm{CO}_{2}$ on economic growth in ASEAN 8. Procedia-Social and Behavioral Sciences, 35: pp. 389-397.

Chen, H., Jia, B., \& Lau, S. S. Y. (2008). Sustainable urban form for Chinese compact cities: challenges of a rapid urbanized economy. Habitat International, 32: pp. 28-40.

Chen, M., Zhang, H., Liu, W., \& Zhang, W. (2014). The Global Pattern of Urbanization and Economic Growth: Evidence from the Last Three Decades. PLoS ONE 9(8):

Dhakal, S. (2009). Urban energy use and carbon emissions from cities in China and policy implications. Energy Policy, 37: pp. 4208-4219. 
Fodha, M., \& Zaghdoud, O. (2010). Economic growth and pollutant emissions in Tunisia: an empirical analysis of the environmental Kuznets curve. Energy Policy, 38: pp.1150-1156.

Gokmenoglu, K. K., \& Sadeghieh, M. (2019). Financial Development, $\mathrm{CO}_{2}$ Emissions, Fossil Fuel Consumption and Economic Growth: The Case of Turkey. Strategic Planning for Energy and the Environment, 38(4): pp.7-28.

Gonzalez, D. \& Martinez, M. (2012). Changes in $\mathrm{CO}_{2}$ emission intensities in the Mexican industry, Energy Policy, 51 : pp.149-163.

Hammami, S., \& Saidi, K. (2015). The impact of energy consumption and $\mathrm{CO}_{2}$ emissions on economic growth: Fresh evidence from dynamic simultaneous-equations models. Sustainable Cities and Society, 14: pp. 178-186.

Hassan, S.(2018). Dynamic Impact of Energy Consumption, Private Investment and Financial Development on Environmental Pollutions: Evidence from Malaysia. International Journal of Energy Economics and Policy, 8(4): pp. 63-69.

Hope, K. R. (1998). Urbanization and urban growth in Africa. Journal of Asian and African Studies 33: pp.345-358.

Hosseini, M. H., \& Kaneko, S. (2013). Can Environmental Quality Spread Through Institutions?. Energy Policy, 56(C), pp. 312-321.

Jamel, L., \& Derbali, A. (2016). Do energy consumption and economic growth lead to environmental degradation? Evidence from Asian economies. Cogent Economics \& Finance, 4(1), 1170653.

Kasman A., \& Duman, Y. S. (2015). $\mathrm{CO}_{2}$ emissions, economic growth, energy consumption, trade and urbanization in new EU member and candidate countries: a panel data analysis. Economic Modelling, 44 : pp. 97-103.

Kizilkaya, O. (2017). The impact of economic growth and foreign direct investment on $\mathrm{CO}_{2}$ emissions: the case of Turkey. Turkish Economic Review, 4(1): pp. 106-118.

Liddle, B. (2004). Demographic dynamics and per capita environmental impact: using panel regressions and household decompositions to examine population and transport. Population and Environment, 26: pp. 23-39.

Liu, X., \& Bae, J.(2018). Urbanization and industrialization impact of $\mathrm{CO}_{2}$ emissions in China. Journal of Cleaner Production, 172 : pp.178-186.

Malik, N., Asmi, F., Ali, M., \& Rehman, M. (2017). Major Factors Leading Rapid Urbanization in China and Pakistan: A Comparative Study.

Mohd, S., Sulaiman, J., \& Saboori, B. (2016). Environmental Kuznets curve and energy consumption in Malaysia: A cointegration approach. Energy Sources, Part B: Economics, Planning, and Policy, 11(9): pp.861-867.

Montgomery, M. R., Stren, R., Cohen, B., \& Read, H, E. eds . (2004). Cities Transformed: Demographic Change and its Implications in the Developing World. London: Earthscan.

Moya, J. A., \& Pardo, N. J. (2013). The potential for improvements in energy efficiency and $\mathrm{CO}_{2}$ emissions in the EU27 iron and steel industry under different payback periods, journal of Cleaner production, 52: pp. 71-83.

Munir, S., \& Khan, A. (2014). Impact of Fossil Fuel Energy Consumption on $\mathrm{CO}_{2}$ Emissions: Evidence from Pakistan (1980-2010). Pakistan Development Review, 53(4): pp. 327.

Pata, U. (2017). The effect of urbanization and industrialization on carbon emissions in Turkey: evidence from ARDL bounds testing procedure. Environ Sci Pollut Res Int. 25(8): pp.7740-7747.

Pesaran, M. H., Shin, Y., \& Smith, R. J. (2001). Bounds testing approaches to the analysis of level relationships. Journal of Applied Economics, 16: pp.289-326

Pesaran, H. M., \& Shin, Y. (1999). Autoregressive distributed lag modeling approach to cointegration analysis. In: Storm S (ed) Econometrics and economic theory in the 20th century: the Ragnar Frisch centennial symposium. Cambridge University Press, Cambridge.

Peters, G. P., Weber, C. L., \& GuanDabo. (2007). China's growing $\mathrm{CO}_{2}$ emissions: A race between increasing consumption and efficiency gains. Environmental Science and Technology, 41(17): pp. 5939-5944. 
Pugh, C. (1995). Urbanization in developing countries: an overview of the economic and policy issues in the 1990s. Cities 12: pp. 381-398.

Raheem, I., \& Ogebe, J. (2017). $\mathrm{CO}_{2}$, urbanization and industrialization: Evidence from a direct and indirect heterogeneous panel analysis. International general of Management of environmental quality, 28(6): pp.851-867.

Rayhan, I., Akhtar, K., Safiqul, M. I., \& Amzad, M. H. (2018). Impact of Urbanization and Energy Consumption on $\mathrm{CO} 2$ Emissions in Bangladesh: An ARDL Bounds Test Approach. International Journal of Scientific \& Engineering Research, 9(6):

Sadorsky, P. (2015). The effect of urbanization on $\mathrm{CO}_{2}$ emissions in emerging Economies. Energy Economics, 41: pp.147-153.

Saeed, S., Ahmad, A., Liu, Q. J., Nizami, S. M., \&. Mannan, A. (2018). Carbon emission from deforestation, forest degradation and wood harvest in the temperate region of Hindukush Himalaya, Pakistan between 1994 and 2016. Land use policy, 78: pp.781-790.

Sarkodie, S, A., \& Owusu, P, A. (2017). Carbon dioxide emissions, GDP per capita, industrialization and population: An evidence from Rwanda. Environmental Engineering Research, 22(1): pp.116-124

Shahbaz, M. A., Chaudhary, \& Ozturk, I. (2017). Does urbanization cause increasing energy demand in Pakistan? Empirical evidence from STIRPAT model. Energy, 122(C): pp. 83-93.

Shahbaz, M., Khraief, N., Salahuddin, G. S., \& Ozturk, I. (2014). Environmental Kuznets curve in an open economy: A bounds testing and causality analysis for Tunisia. Renewable and Sustainable Energy Reviews, 34: pp. $325-336$.

Shahbaz, M., Loganathan, N., \& Sbia, R. (2015). The effect of urbanization, affluence and trade openness on energy consumption: A time series analysis in Malaysia. Renewable and Sustainable Energy Reviews, 47: pp. $683-693$.

Siddique, H. M. A., Majeed, M. T., \& Ahmad, H. K. (2016). The Impact of Urbanization and Energy Consumption on $\mathrm{CO}_{2}$ Emissions in South Asia. South Asian Studies (1026-678X), 31(2).

Smyth, R. \& Lean, H. H. (2010). $\mathrm{CO}_{2}$ emissions, electricity consumption and output in ASEAN. Applied Energy, 87: pp. 1858-1864.

Song, T., Zheng, T., \& Tong, L. (2008). An empirical test of the environmental Kuznets curve in China: a panel co integration approach. China Economic Review, 19: pp. 381-392.

Thao, N. T. N., \& Chon, V. L. (2015). Nonrenewable, renewable energy consumption and economic performance in OECD countries: A stochastic distance function approach.

Wolde, E. T. (2015). Economic Growth and Environmental Degradation in Ethiopia: An Environmental Kuznets Curve Analysis Approach. Journal of Economics and International Finance, 7(4) : pp. 72 - 79.

$\mathrm{Xu}, \mathrm{B}$., \& Lin, B. (2015). How industrialization and urbanization process impacts on $\mathrm{CO}_{2}$ emissions in China: Evidence from nonparametric additive regression models. Energy Economics, 48: pp188-202.

Xuemei, B., Jin, C., \& Peijun, S. (2012). Landscape urbanization and economic growth in China: Positive feed backs and sustainability dilemmas. Environmental Science and Technology, 46(1): pp.132-139.

Yang, L., Yuan, S., \& Sun, L. (2007). The Relationships between Economic Growth and Environmental Pollution Based on Time Series Data: An Empirical Study of Zhejiang Province. Journal of Cambridge Studies, 7(1): pp. $33-42$.

York, R. (2007). Demographic trends and energy consumption in European Union Nations, 1960-2025. Social Science Research, 36(3): pp. 855-872.

Zhao, R., Huang, X., Zhong, T., Liu, Y., \& Chuai, X. (2014). Carbon flow of urban system and its policy implications: the case of Nanjing. Renewable and Sustainable Energy Reviews, 33: pp. 589-601.

Zhaohua, W., Fangchao, Y., \& Yixiang. (2012). An empirical research on the influencing factors of regional $\mathrm{CO}_{2}$ emissions: Evidence from Beijing city, China. Applied Energy, 100: pp. 277-284.

Zou, Q., Chen, X., \& Lv, J. N. (2014). The environmental Kuznets curve and effect factors of $\mathrm{CO}_{2}$ emissions in China: dynamic econometric test based on ARDL model. Advanced Materials Research, 962: pp. 1670-1675. 